\title{
Effect of Combination of Alumina-Silica Rich Minerals with Fly Ash on Structural Behaviour of the Basalt Fibre Reinforced Geopolymer Concrete
}

\author{
M.Sakthivel, S. Aravind, R.G.Dhilip kumar, S.P.Kanniyappan
}

\begin{abstract}
Cement production is one of the major $\mathrm{C02}$ emitter which contributes around $8 \%$ of the world's carbon dioxide emissions. So the Engineers are in the need of developing alternate material for cement to reduce the effect of vulnerable climatic changes in the world. This paper aims at presenting the experimental study on effect of combination of silica rich minerals with fly ash based geopolymer concrete. Fly ash was found to be successful in enhancing the performance of geopolymer concrete. The Utilization of more industrial wastes will promisingly contribute for reducing the environmental pollution. To determine the effective admixture combination with fly ash in geopolymer concrete, industrial wastes such as silica fume, GGBS, Metakaolin, palm oil fly ash were used. The concrete mixes were designed with 60 percentile of fly ash and 40 percentile of other industrial wastes to replace the cement in Geopolymer concrete. The Concrete specimens were casted and cured at different conditions namely Oven curing, Steam curing and sunlight. The Compressive, tensile and flexural strength behaviors were determined for the designed concrete mixes and the results were presented.
\end{abstract}

Keywords: Basalt fibre, curing, fly ash, Geo-polymer, GGBS, Metakaolin, POFA, Silica fume.

\section{INTRODUCTION}

Geopolymer concrete is one such Ecofriendly alternative which Contributes for reducing the $\mathrm{C} 02$ emissions and also offers the properties like better structural performance, Fire resistance, Thermal insulation and viable use of Industrial wastes. This concrete has been used for construction of pavements, retaining walls, water tanks, precast bridge decks. In geopolymer concrete the binding

Revised Manuscript Received on December 30, 2019.

* Correspondence Author

Sakthivel M*, Civil department, R.M.K. Engineering College, Kavaraipettai, Tamil nadu, India. Email: msv.civil@rmkec.ac.in

Aravind S, Civil department R.M.K. Engineering College, Kavaraipettai, Tamil nadu, India. Email: ads.civil@rmkec.ac.in

Dhilipkumar.R.G, Civil department R.M.K. Engineering College, Kavaraipettai, Tamil nadu, India. Email: rgd.civil@rmkec.ac.in

Kaniyappan.S.P, Civil department R.M.K. Engineering College, Kavaraipettai, Tamil nadu, India. Email: spk.civil@rmkec.ac.in

(C) The Authors. Published by Blue Eyes Intelligence Engineering and Sciences Publication (BEIESP). This is an open access article under the CC BY-NC-ND license (http://creativecommons.org/licenses/by-nc-nd/4.0/) action is produced by reaction of alkaline solution with the material that is rich in Silica (Si) and Alumina (Al).

The alkaline solution is usually comprises of sodium silicate and sodium hydroxide solution. Good bonding effects can be achieved through Polymerization reaction with the sodium hydroxide, or potassium hydroxide and the addition of silicates as an activator. The Polymerization is accelerated by the inclusion of sodium silicate in sodium hydroxide solution or potassium silicate in potassium hydroxide solution. The oxygen bond with the water molecule gets condensate by the reaction of silicon or aluminum hydroxide molecules; thereby it gives the bonding of silica or alumina tetrahedral. From the previous work on geopolymer concrete, it is understood that the effective bonding can be obtained with high alumina and silica content. Hence the minerals to be used as binder in geopolymer concrete should be rich in alumina and silica content for making the concrete an effective one. In this study, the industrial wastes namely silica fume, GGBS, Metakaolin, palm oil fly ash were used to determine the structural performance of the geopolymer concrete made with the different combinations of industrial wastes with fly ash which is found to be successful in the making of geopolymer concrete for the past two decades. It is also understood that the silicon or aluminum hydroxide molecules undergo a condensation reaction where adjacent hydroxyl ions from these near neighbors condense to form an oxygen bond linking the water molecule, and it is seen that each oxygen bond is formed as a result of a condensation reaction and thereby bonds the neighboring $\mathrm{Si}$ or $\mathrm{Al}$ tetrahedral.

\section{METHODOLOGY}

The alumina-silica rich minerals were selected to incorporate in the design mixes for Geopolymer concrete to simulate the effective binding property. The fly ash have developed as familiar binding mineral in the construction industry and stands next to the cement in terms of production and sale. The Optimization of Other industrial wastes in the production of alternative binding materials help to reduce the vulnerable effects from the Production of cement. In this study, the industrial wastes namely GGBS, Silica fume, POFA, Metakaolin were selected to prepare a design mixes of Geopolymer concrete to determine the effective combination with fly ash on structural performance of various design mixes. 


\section{Effect of Combination of Alumina-Silica Rich Minerals with Fly Ash on Structural Behaviour of the Basalt Fibre Reinforced Geopolymer Concrete}

The fly ash is kept as major contribution (60\%) in the total volume of cement and the remaining $40 \%$ of the content were to be contributed by other industrial wastes. The sodium silicate with sodium hydroxide solution was found to be a successful activators for accelerate the polymerization process. The Concentration of solutions was selected as 10 molarity from the trial mixes of the concrete. The Construction market needs an economical batch production with high fluidity for the effective placing of concrete in the high rise buildings through the pumps. The high fluidity with the balanced economical design in concrete production can be achieved through the super plasticizers. The polycarboxylate based super plasticizer was found to be successful in the polymerization process of previous works. The two percentile of polycarboxylate (PC1) was to be added with the weight of cement in all design mixes. The five different concrete mixes are to be designed with the combination of (Fly ash + cement, Fly ash + GGBS, Fly ash + Silica fume, Fly ash + POFA and Fly ash + Metakaolin) and three different curing methods namely oven curing , steam curing and sunlight curing were selected for the process of strength development. The Structural performance of designed concrete mixes with respect to the curing treatments is to be determined.

\section{MATERIALS USED}

Fly ash is considered as best supplementary cementitious material in concrete for achieving the cementitious properties when chemically react with calcium hydroxide at ordinary temperatures.

\section{A. Fly Ash}

The Optimization of fly ash will maximize the technical, environmental, and economic benefits without significantly impacting the rate of construction. The class F Fly ash is used in this study which is obtained from Neyveli thermal power station.

Table-I: Chemical Composition of fly ash

\begin{tabular}{|l|l|}
\hline Chemical composition & Percentage \\
\hline Silicon dioxide,SiO2 & 62.9 \\
\hline Aluminum oxide, $\mathrm{Al} 2 \mathrm{O}$ & 29.10 \\
\hline Ferric oxide,Fe2O3 & 3.01 \\
\hline Calcium oxide, $\mathrm{CaO}$ & 2.04 \\
\hline Magnesium oxide, $\mathrm{MgO}$ & 0.91 \\
\hline Titanium oxide,TiO2 & 0.64 \\
\hline Potassium oxide,K20 & 0.02 \\
\hline Sodium oxide,Na2O & 1.27 \\
\hline Sulpur trioxide,SO2 & 0.11 \\
\hline
\end{tabular}

\section{B. GGBS}

GGBS (Ground granulated blast furnace slag) is generally used to make durable concrete structures with its high pozzolanic properties. Being a waste byproduct, it can be utilized to an optimum portion in a concrete to reduce the consumption of cement and also to achieve a high durability. The main problem facing with GGBS is that it lacks in attaining the early strength development which affects the construction schedule. This problem can be overcome by the alkaline activators in geopolymer concrete as it obtains the early strength development as well as durable properties.

Table-II: Chemical Properties of GGBS

\begin{tabular}{|l|l|}
\hline \multicolumn{1}{|c|}{ Chemical composition } & Percentage \\
\hline Silicon dioxide,SiO2 & 38.49 \\
\hline Aluminum oxide, Al2O & 14.40 \\
\hline Ferric oxide,Fe2O3 & 2.11 \\
\hline Calcium oxide, $\mathrm{CaO}$ & 38.04 \\
\hline Magnesium oxide, MgO & 4.91 \\
\hline Titanium oxide,TiO2 & 0.94 \\
\hline Potassium oxide,K20 & 0.32 \\
\hline Sodium oxide,Na2O & 0.27 \\
\hline Sulpur trioxide,SO2 & 0.11 \\
\hline Manganese oxide,Mn2O3 & 0.41 \\
\hline
\end{tabular}

\section{POFA}

The Concrete production industries are aiming for better admixtures from the industrial wastes to decreasing the production cost that will reduce the impact on environmental hazards developed from the cement production. Palm oil fuel ash (POFA) is one of the admixtures from the industrial wastes which can be utilized as a partial replacement for cement into the concrete mix for its pozzolanic rich properties. It can also be used in Geopolymer concrete due to its high silica content. POFA was found to be successful in making an effective Geopolymer concrete in terms of structural performance.

Table-III: Chemical Composition of POFA

\begin{tabular}{|l|l|}
\hline Chemical Composition & Percentage \\
\hline Silicon dioxide, $\mathrm{SiO} 2$ & 44.3 \\
\hline Aluminum oxide, $\mathrm{Al} 2 \mathrm{O}$ & 8.7 \\
\hline Ferric oxide, $\mathrm{Fe}_{2} \mathrm{O}_{3}$ & 10.3 \\
\hline Calcium oxide, $\mathrm{CaO}$ & 8.6 \\
\hline Magnesium oxide, $\mathrm{MgO}$ & 4.1 \\
\hline Titanium oxide, $\mathrm{TiO} 2$ & 1.3 \\
\hline Potassium oxide, $\mathrm{K} 2 \mathrm{O}$ & 3.6 \\
\hline Sodium oxide, $\mathrm{Na} 2 \mathrm{O}$ & 0.4 \\
\hline Sulphur trioxide, $\mathrm{SO} 3$ & 2.84 \\
\hline LOI $\left(1000^{\circ} \mathrm{C}\right)$ & 17.16 \\
\hline
\end{tabular}




\section{Silica fume}

Silica fume is a byproduct of producing silicon metal or ferrosilicon alloys. One of the most beneficial uses for silica fume is in concrete. Because of its chemical and physical properties, it is a very reactive pozzolan. Concrete containing silica fume can have very high strength and can be very durable.

Table-IV: Chemical Composition of Silica fume

\begin{tabular}{|c|c|}
\hline Chemical Composition & Percentage \\
\hline Silicon dioxide, $\mathrm{SiO}_{2}$ & 95.28 \\
\hline Aluminum oxide, $\mathrm{Al}_{2} \mathrm{O}$ & 1.32 \\
\hline Ferric oxide, $\mathrm{Fe}_{2} \mathrm{O}_{3}$ & 0.18 \\
\hline Calcium oxide, $\mathrm{CaO}$ & 0.53 \\
\hline Magnesium oxide, $\mathrm{MgO}$ & 0.12 \\
\hline Titanium oxide, $\mathrm{TiO}_{2}$ & 0.10 \\
\hline Potassium oxide, $\mathrm{K}_{2} \mathrm{O}$ & 0.09 \\
\hline Sodium oxide, $\mathrm{Na}_{2} \mathrm{O}$ & 0.10 \\
\hline Sulphur trioxide, $\mathrm{SO}_{3}$ & 0.31 \\
\hline LOI (1000 $\left.{ }^{\circ} \mathrm{C}\right)$ & 1.97 \\
\hline
\end{tabular}

\section{E. Metakaolin}

Metakaolin (MK) is one of the industrial wastes which is obtained from the calcination of kaolin clay at temperatures ranging from 700 to 800 o C. It can be included in concrete for its highly reactive properties which influences the fresh, hardened concrete properties and durability. Metakaolin is rich in alumina and silica which helps to achieve the effective bonding when it used in Geopolymer concrete with activators.

Table-V: Chemical Composition of Metakaolin

\begin{tabular}{|c|c|}
\hline Chemical Composition & Percentage \\
\hline Silicon dioxide, $\mathrm{SiO} 2$ & 55.3 \\
\hline Aluminum oxide, Al2O & 39.7 \\
\hline Ferric oxide,Fe2O3 & 0.28 \\
\hline Calcium oxide, $\mathrm{CaO}$ & 3.26 \\
\hline Magnesium oxide, $\mathrm{MgO}$ & 0.10 \\
\hline Titanium oxide, TiO2 & - \\
\hline Potassium oxide, K2O & 0.60 \\
\hline Sodium oxide, Na2O & 0.04 \\
\hline Sulphur trioxide, SO3 & - \\
\hline
\end{tabular}

\section{LOI $\left(1000^{\circ} \mathrm{C}\right)$}

0.72

\section{F. Basalt fiber}

Basalt fiber is a new arrival to the making of fiber reinforced concrete which is obtained from the rapid cooling of lava at the surface of a planet .It has a more beneficial properties over the other fibers in terms of better strength characteristics, highly resistant to alkaline, acidic and salt attack which makes a effective concrete design for the applications of bridge and shoreline structures.

Table-VI: Mechanical properties of Basalt fibre

\begin{tabular}{|c|c|}
\hline Property & Value \\
\hline Length(mm) & 24 \\
\hline Diameter(mm) & 18 \\
\hline Aspect ratio(L/D) & 1.33 \\
\hline Specific gravity & 2.67 \\
\hline Melting Point ( $\left.{ }^{0} \mathrm{c}\right)$ & 1500 \\
\hline Tensile strength(N/mm2) & 2900 \\
\hline Elastic modulus(GPa) & 122 \\
\hline Elongation at break & 3.72 \\
\hline
\end{tabular}

\section{G. Super Plasticizer}

Modified polycarboxylate based super plasticizers has been selected to incorporate in the geopolymer mix for its performance in workability and compressive strength [1]. It has the tendency to disperse the particle suspension and there by achieving the fluidity characteristics instantly.

Table-VII: Mechanical properties of Super plasticizer

\begin{tabular}{|c|c|c|}
\hline Color & $\mathbf{p H}\left(\mathbf{2 0}^{\mathbf{}} \mathbf{c}\right)$ & Density(kg/m3) \\
\hline Light brown & 6.8 & 1100 \\
\hline
\end{tabular}

\section{H. Alkaline Activators}

The Combination of Potassium silicate with potassium hydroxide or Sodium silicate with Sodium hydroxide was found to be an effective activator of geopolymer concrete in the previous studies. In the present investigation, Sodium silicates with Sodium hydroxide solution were used as activator in the Geopolymer mix with Concentration of $10 \mathrm{M}$ and ratio of silicate to hydroxide in the range of 0.45 to 0.46.The Parameters which are selected from previous work to accelerate the polymerization process are concentration of solution and silicates to hydroxide ratio.

\section{EXPERIMENTAL INVESTIGATION}

Based on the results obtained from the physical properties of the minerals used, the various concrete mixes were designed with respect to combination of fly ash with cement, GGBS, Silica fume, POFA and Metakaolin .The Concrete mixes were designed to achieve the target strength of 40Mpa. In this study, 60 percentile of binder used is fly ash and 40 percentile of binder replaced with various minerals such as cement,

\section{Published By:}




\section{Effect of Combination of Alumina-Silica Rich Minerals with Fly Ash on Structural Behaviour of the Basalt Fibre Reinforced Geopolymer Concrete}

GGBS, Silica fume, POFA and Metakaolin in the respective mixes. The fly ash is kept as ideal binder in all the designed mixes because it was found to be successful in the structural and durable performance of Geo polymer concrete and also for its Economical availability. The various mix proportions and their quantity used is mentioned in the Table IX.

Table-VIII: Number of Specimens Casted

\begin{tabular}{|c|c|c|c|c|c|}
\hline \multirow[t]{2}{*}{ Test } & \multirow[t]{2}{*}{ Proportion of Fly ash with } & \multicolumn{3}{|c|}{ Type of Curing Treatment } & \multirow[b]{2}{*}{$\begin{array}{l}\text { No. } \\
\text { of } \\
\text { specimens }\end{array}$} \\
\hline & & Oven & Steam & Sunlight & \\
\hline \multirow{4}{*}{$\begin{array}{l}\text { Compressive test } \\
\text { (150mm cube) }\end{array}$} & GGBS & 6 & 6 & 6 & 18 \\
\hline & POFA & 6 & 6 & 6 & 18 \\
\hline & Silica fume & 6 & 6 & 6 & 18 \\
\hline & Metakaolin & 6 & 6 & 6 & 18 \\
\hline \multicolumn{5}{|l|}{ Number of cubes casted } & 90 \\
\hline \multirow{5}{*}{$\begin{array}{l}\text { Flexural test } \\
\text { (750x150x 150mm Prism) }\end{array}$} & Cement & 6 & 6 & 6 & 18 \\
\hline & GGBS & 6 & 6 & 6 & 18 \\
\hline & POFA & 6 & 6 & 6 & 18 \\
\hline & Silica fume & 6 & 6 & 6 & 18 \\
\hline & Metakaolin & 6 & 6 & 6 & 18 \\
\hline \multicolumn{5}{|l|}{ Number of Prisms casted } & 90 \\
\hline & GGBS & 6 & 6 & 6 & 18 \\
\hline & POFA & 6 & 6 & 6 & 18 \\
\hline & Silica fume & 6 & 6 & 6 & 18 \\
\hline & Metakaolin & 6 & 6 & 6 & 18 \\
\hline \multicolumn{5}{|l|}{ Number of Cylinders casted } & 90 \\
\hline
\end{tabular}

Table-IX: Mix proportions of Geopolymer Concrete

\begin{tabular}{|c|c|c|c|c|c|c|c|c|c|}
\hline $\begin{array}{l}\text { Mix } \\
\text { ID }\end{array}$ & $\begin{array}{c}\text { Combination of } \\
\text { Fly ash with } \\
40 \% \text { of }\end{array}$ & $\begin{array}{l}\text { Fly ash } \\
(\mathrm{kg} / \mathrm{m} 3)\end{array}$ & $\begin{array}{c}\text { GGBS/ } \\
\text { POFA/ } \\
\text { Silica fume/ } \\
\text { Metakaolin } \\
(\mathrm{kg} / \mathrm{m} 3) \\
\end{array}$ & $\begin{array}{c}\text { Water } \\
(\mathrm{kg} / \mathrm{m} 3)\end{array}$ & $\begin{array}{c}\text { Basalt } \\
(\mathrm{kg} / \mathrm{m} 3)\end{array}$ & $\begin{array}{c}\text { F.A } \\
(\mathrm{kg} / \mathrm{m} 3)\end{array}$ & $\begin{array}{c}\mathrm{NaOH} \\
(\mathrm{kg} / \mathrm{m} 3)\end{array}$ & $\begin{array}{c}\mathrm{Na} 2 \mathrm{SiO} 3 \\
(\mathrm{~kg} / \mathrm{m} 3)\end{array}$ & $\begin{array}{c}\text { C.A } \\
(\mathrm{kg} / \mathrm{m} 3)\end{array}$ \\
\hline MI 1 & Cement & 225.74 & 159.26 & 156.01. & 7.36 & 525.26 & 100.98 & 47.22 & 1289 \\
\hline MI 2 & POFA & 235.2 & 156.8 & 155.23 & 7.84 & 563.69 & 107.8 & 48.68 & 1339 \\
\hline MI 3 & Silica fume & 221.4 & 147.6 & 146.12 & 7.38 & 527.67 & 101.47 & 46.12 & 1276 \\
\hline MI 4 & Metakaolin & 237.6 & 158.4 & 156.81 & 7.92 & 566.28 & 108.9 & 46.12 & 1352 \\
\hline MI 5 & GGBS & 231 & 154 & 156.24 & 7.7 & 554 & 106 & 48 & 1314 \\
\hline
\end{tabular}

Totally 90 specimens were casted each to determine the compressive, flexural and tensile behavior of Geopolymer concrete respectively with various designed mixes. The casted specimens were cured for 28days under different treatment conditions such as Oven, Steam and Sunlight. The Cured specimens under different treatment methods were tested for compression, flexure and tension. The structural behavior of the Geopolymer concrete with various combination of fly ash was examined from the test results. The Effectiveness of the Geopolymer concrete in combination with fly ash and in terms of effectiveness in curing treatment was presented.

\section{RESULTS AND DISCUSSION}

\section{A.Compressive strength}

The Cube specimens were carried out for a compression test after 7days and 28days of curing under different conditions. The Compressive strength results were presented in the Table $X$. The Early strength development obtained better in metakaolin combination with fly ash as compared to design mix made with combination of cement. The Early age strength is not so good in the design mix combination with Silica fume due to its low alumina content there by lacks in achieving the binding property earlier through the process of polymerization.

Table-X: Compressive strength results

\begin{tabular}{|c|c|c|c|c|c|c|}
\hline Combination & $\begin{array}{l}\text { 7days oven } \\
\text { curing }\end{array}$ & $\begin{array}{l}7 \text { days steam } \\
\text { curing }\end{array}$ & $\begin{array}{l}\text { 7days sunlight } \\
\text { curing }\end{array}$ & $\begin{array}{l}\text { 28days oven } \\
\text { curing }\end{array}$ & $\begin{array}{l}\text { 28days steam } \\
\text { curing }\end{array}$ & $\begin{array}{l}28 \text { days sunlight } \\
\text { curing }\end{array}$ \\
\hline Cement & 17.868 & 20.79 & 25.0914 & 29.78 & 34.65 & 40.47 \\
\hline
\end{tabular}




\begin{tabular}{|l|l|l|l|l|l|l|}
\hline GGBS & 19.968 & 23.772 & 27.4536 & 33.28 & 39.62 & 44.28 \\
\hline POFA & 22.692 & 24.756 & 29.7352 & 37.82 & 47.96 \\
\hline Silica fume & 17.556 & 19.836 & 24.7752 & 29.26 & 33.06 \\
\hline Metakaolin & 24.354 & 27.066 & 30.6776 & 40.59 & 45.11 & 49.48 \\
\hline
\end{tabular}

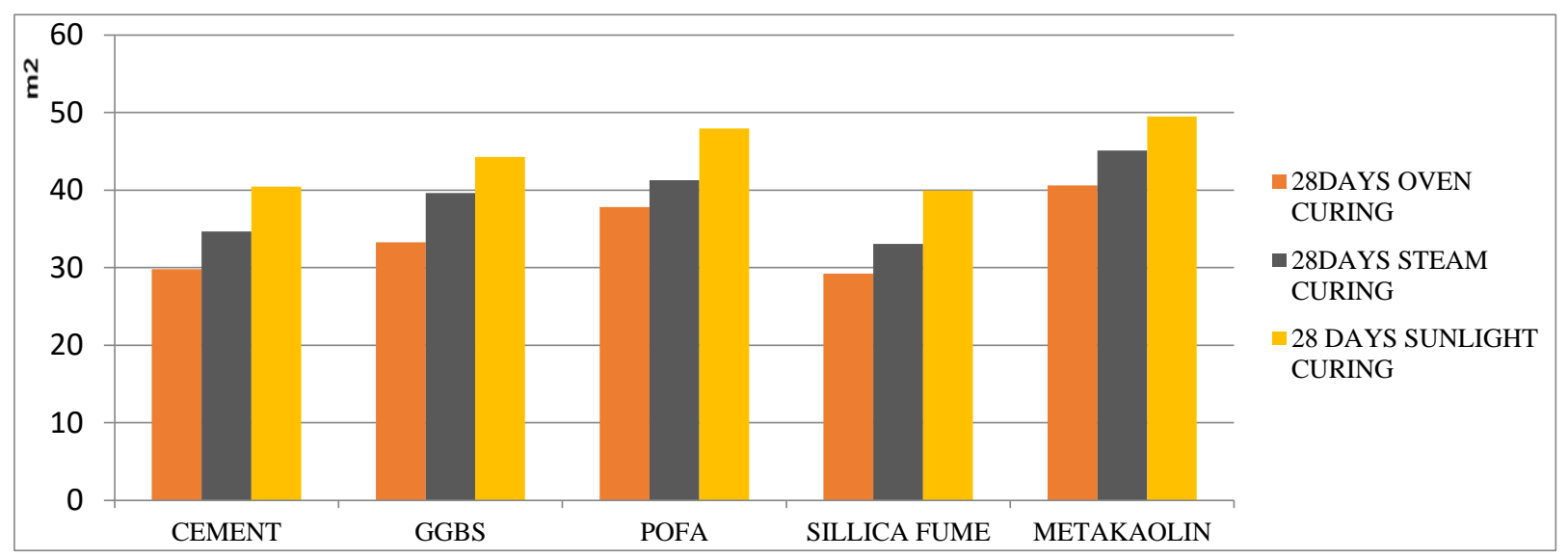

Fig 1.Compressive strength Effect on combination of fly ash with various design mixes under different Curing treatments

\section{B.Flexural strength}

The Prism specimens of size $(750 x 150 x 150 \mathrm{~mm})$ were carried out for flexural test under two point loading after 7 days and 28days of curing under different conditions. The Flexural strength results were presented in the Table XI. From the results, it was found that the flexural strength obtained was good in the design mix with Combination of metakaolin and POFA. It is to mention that these two design mixes have obtained the high workability in the fresh state due to its porous nature. The high workable mix combined with basalt fibre enhanced the flexural strength effectively than the other design mix combinations.

Table-XI: Flexural strength results

\begin{tabular}{|l|l|l|l|l|l|l|}
\hline Combination & $\begin{array}{l}\text { 7days } \\
\text { oven curing }\end{array}$ & $\begin{array}{l}\text { 7 days } \\
\text { steam curing }\end{array}$ & $\begin{array}{l}\text { 7days } \\
\text { sunlight curing }\end{array}$ & $\begin{array}{l}\text { 28days } \\
\text { oven curing }\end{array}$ & $\begin{array}{l}\text { 28days } \\
\text { steam curing }\end{array}$ & $\begin{array}{l}\text { 28 days } \\
\text { sunlight curing }\end{array}$ \\
\hline Cement & 1.995408 & 2.327976 & 2.7714 & 3.2184 & 3.7548 & 4.47 \\
\hline GGBS & 2.111472 & 2.463384 & 2.9326 & 3.4056 & 3.9732 & 4.73 \\
\hline POFA & 2.169504 & 2.531088 & 3.0132 & 3.4992 & 4.0824 & 4.86 \\
\hline Silica fume & 2.026656 & 2.364432 & 2.8148 & 3.2688 & 3.8136 & 4.54 \\
\hline Metakaolin & 2.258784 & 2.635248 & 3.1372 & 3.6432 & 4.2504 & 5.06 \\
\hline
\end{tabular}

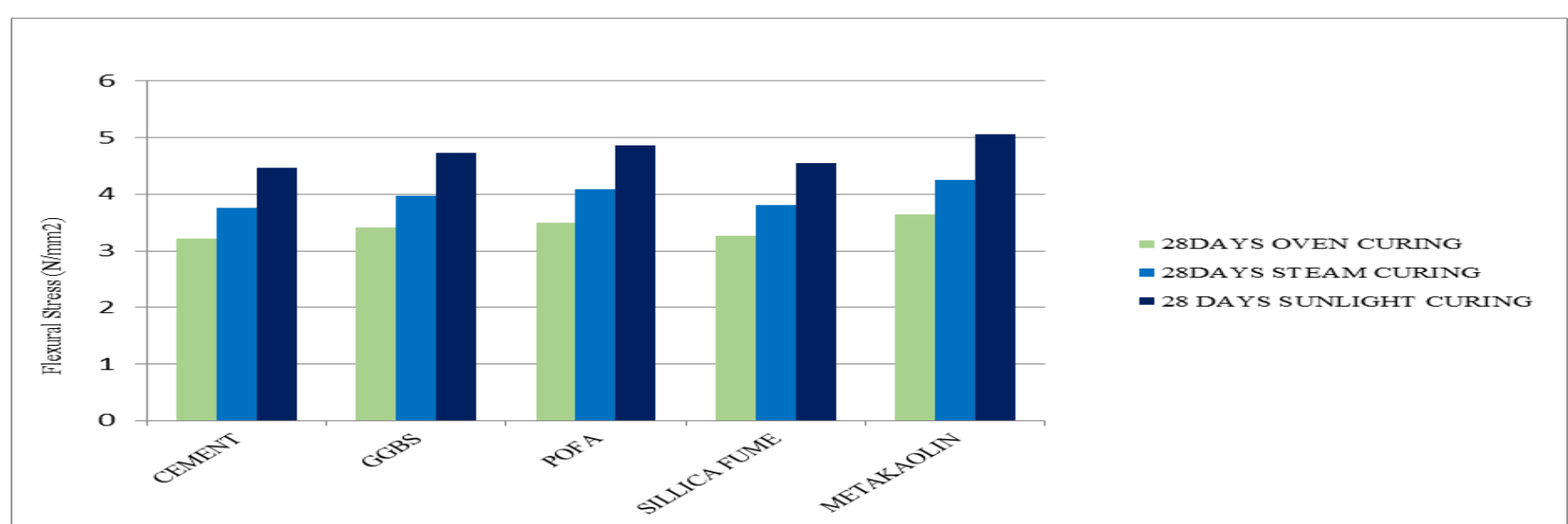

Fig 2.Flexural strength Effect on combination of fly ash with various design mixes under different Curing treatments

\section{A. Split tensile strength}

The Cylinder specimens of size (150x 300mm) were carried out for split tensile test after 7days and 28days of curing under different conditions. The Flexural strength results were presented in the Table XII.

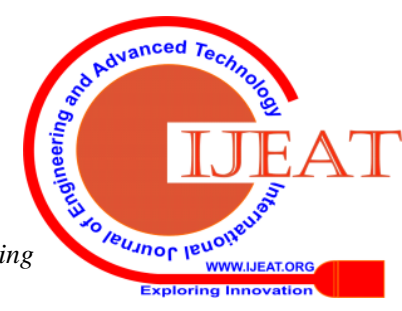




\section{Effect of Combination of Alumina-Silica Rich Minerals with Fly Ash on Structural Behaviour of the Basalt}

Fibre Reinforced Geopolymer Concrete

Table-XII: Split tensile strength results

\begin{tabular}{|c|c|c|c|c|c|c|}
\hline Combination & $\begin{array}{l}\text { 7days oven } \\
\text { curing }\end{array}$ & $\begin{array}{l}7 \text { days steam } \\
\text { curing }\end{array}$ & $\begin{array}{l}\text { 7days sunlight } \\
\text { curing }\end{array}$ & $\begin{array}{l}\text { 28days oven } \\
\text { curing }\end{array}$ & $\begin{array}{l}\text { 28days steam } \\
\text { curing }\end{array}$ & $\begin{array}{l}28 \text { days sunlight } \\
\text { curing }\end{array}$ \\
\hline Cement & 1.888272 & 2.176758 & 2.6226 & 3.0456 & 3.5109 & 4.23 \\
\hline GGBS & 1.968624 & 2.269386 & 2.7342 & 3.1752 & 3.6603 & 4.41 \\
\hline POFA & 2.281104 & 2.629606 & 3.1682 & 3.6792 & 4.2413 & 5.11 \\
\hline Silica fume & 1.790064 & 2.063546 & 2.4862 & 2.8872 & 3.3283 & 4.01 \\
\hline Metakaolin & 2.41056 & 2.77884 & 3.348 & 3.888 & 4.482 & 5.4 \\
\hline
\end{tabular}

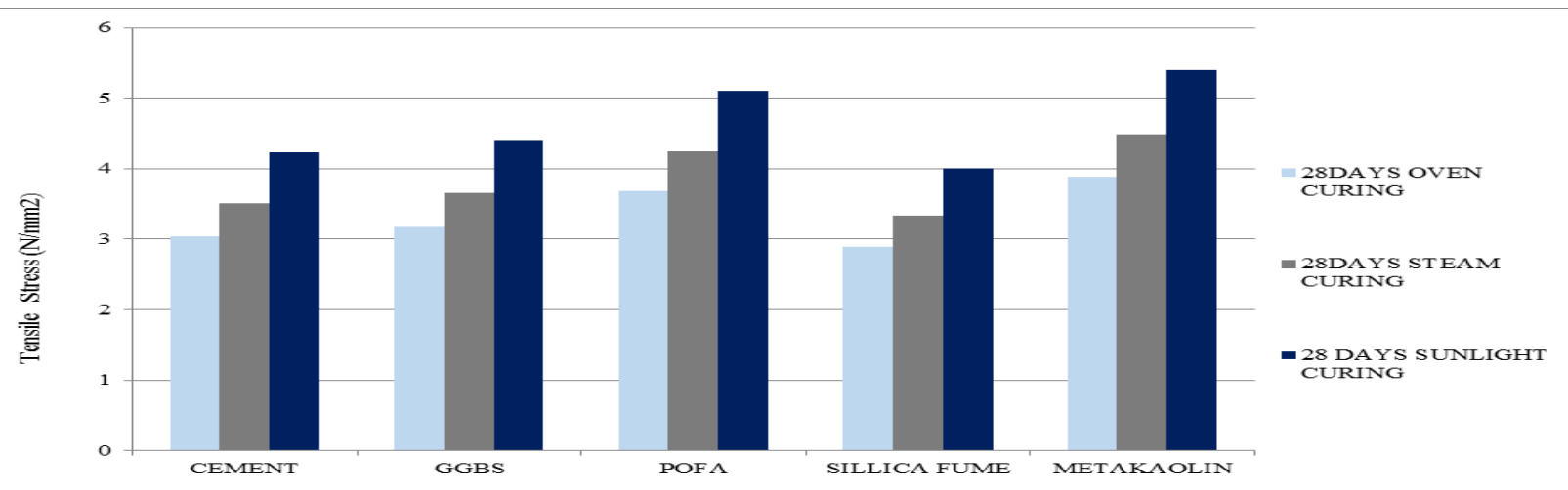

Fig 3.Tensile strength Effect on combination of fly ash with various design mixes under different Curing treatments

\section{CONCLUSION}

From the above test results, the following conclusions have been drawn with the observations.

1) The Polycarboxylate plasticizer helps to achieve the higher fluidity in concrete in all the design mixes especially with the Geopolymer mix combination of Metakaolin and POFA.

2) Incorporation of Basalt fibres in design mixes especially with the combination of metakaolin, POFA, GGBS was found to be effective in achieving the flexural and tensile strength.

3) Under different curing Conditions, it is observed that the optimum strength was obtained from the curing under sunlight treatment.

4) In terms of workability, the high workability and as well as structural performance was obtained in design mixes with the combination of Metakaolin and POFA. These design mixes can be implemented in the applications of concrete placing through pumps.

5) The Early age strength development was found to be sound in design mixes with the combination of Metakaolin and POFA and poor in design mix with the combination of Silica fume.

6) The polymerization process was not developed adequately to obtain better structural performance in design mix with the combination of silica fume due to its poor alumina content.

7) At the same time, effective binding property was achieved through the polymerization process in design mix with the combination of metakaolin due to its rich silica and alumina content

8) Hence it is recommended to make a Geopolymer concrete with mineral which have balancing rich composition of silica and alumina.

9) It is concluded that the overall structural performance of Geopolymer concrete made with the combination of Fly ash with metakaolin sounds better than the other design mixes.

\section{REFERENCES}

1. Ahmad B. Malkawi, "Effects of Alkaline Solution on Properties of the HCFA Geopolymer Mortars," Procedia Engineering, vol. 148, pp.710-717., 2016.

2. Sagar M. Dobariya, Prof. Amit Deb, "An Effect of Alkaline Solution on Strength of Geopolymer Concrete," IJSTE - International Journal of Science Technology \& Engineering, Volno. 4 ,pp.223-228,2018

3. M.F. Nuruddin, A. Kusbiantoro, S. Qazi, M.S. Darmawan,"Development of Geopolymer Concrete with Different Curing Conditions", IPTEK, The Journal for Technology and Science, Vol. 22, pp.24-28,2011.

4. Anil Ronad, V.B.Karikatti, S.S.Dyavanal, "A study on mechanical properties of geopolymer concrete reinforced with basalt fiber," IJRET: International Journal of Research in Engineering and Technology, Vol. 03, pp.1984-1988,2016.

5. D. Naveen Kumar , DR. Kolli Ramujee, " Durability Characteristics of Fiber Reinforced Geopolymer Concrete Incorporated with Fly-ash and GGBS)," International Research Journal of Engineering and Technology (IRJET), Vol. 4, pp.958-969,2017.

6. Joni M , Rexin C , Frank Stephen "Shear Behaviour of M- Sand Based Geoploymer Concrete," SSRG International Journal of Civil Engineering (SSRG-IJCE) - volno.5,pp.6-12,2018.

7. Dr. P. Thamilselvi,, Dr. A. Siva, Dr. Damilola Oyejobi "GEOPOLYMER CONCRETE: OVERVIEW," International Journal of Advanced Research in Engineering and Technology (IJARET), vol.8, pp.10-14., 2017.

8. Seena Simon, A. Hemamathi, J. Jenishtalouis, Strength Assessment on Flyash Based Geopolymer Concrete International Journal of Innovative Technology and Exploring Engineering (IJITEE)., vol. 9, pp. 3956-3960,2019.

9. IS: 10262-1982, "Recommended guide lines for concrete mix design".

10. IS: 456-2000. Plain and Reinforced Concrete- Code of Practice (Fourth Revision), Bureau of Indian Standard, New Delhi. 


\section{AUTHORS PROFILE}

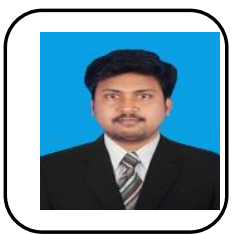

M. Sakthivel, working as Assistant professor at R.M.K.Engineering College. He has gained five years of Teaching Experience. He has obtained her B.E. (Civil) from Adhiparasakthi Engineering College, M.E (Structural Engineering) from Anna University, Coimbatore. He has guided many under graduate projects and published papers in International journals and Conferences. He has attended several National and International Conferences, Workshops, Seminars, Faculty Development and Training programs.. He is a Life member of ISTE.

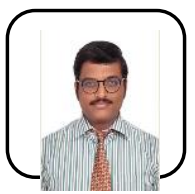

S.Aravind working as Assistant professor at R.M.K.Engineering College.. He has gained more than 7 years of

Teaching Experience. He has obtained her B.E. (Civil) from St.Peter's Engineering College, M.E (Construction Management) from Sree sastha institute of engineering and technology, Chennai. He has guided many under graduate projects. He has attended several National and International Conferences, Workshops, Seminars, Faculty Development and Training programs.. He is a Life member of ISTE

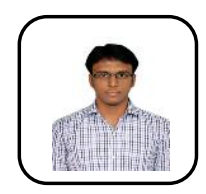

R.G.Dhilip kumar is Assistant Professor, Department of Civil Engineering R.M.K .Engineering College. He obtained his M.E Structural Engineering from PSNA College of Engineering \& Technology, Dindigul. He has published papers in international and National Journals. He is a life time member of professional societies ISTE.

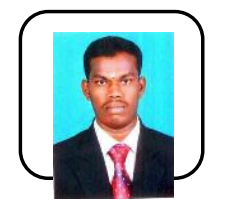

Mr..S.P.Kanniyappan., (B.E (Civil),M.E (Construction Engineering Management),Assistant Professor in Department of Civil Engineering, R.M.K .Engineering College., Kavaraipettai, Tamilnadu ,India. He has nearly 25 publications in various National, International Journals \& Conferences. He is a life time Member in ISTE, International Association of Engineers and Institute of Engineers. 